\title{
Research on Optimization of Informatization Talents Training Mode in Colleges Under the Background of "Innovation 3.0"
}

\author{
Donghong Wang ${ }^{1, \mathrm{a}}$, Fengjiao $\mathrm{Hao}^{2, \mathrm{~b}}$ and Jie Liu ${ }^{1, \mathrm{c}}$ \\ ${ }^{I}$ School of Information Management and Statistics, Hubei University of Economics, China \\ ${ }^{2}$ Hubei Local Taxation Research Center, Hubei University of Economics, China \\ awdhong@hbue.edu.cn, ${ }^{b} 461441987 @ q q . c o m,{ }^{c}$ liujie@hbue.edu.cn
}

\begin{abstract}
The innovation paradigm has evolved from innovation 1.0 and innovation 2.0 to innovation 3.0. In the period of Innovation 3.0, the institutions are required to cultivate talents with innovative consciousness, innovative thinking and innovative ability. Using the RETAIN model, the optimization path of innovation and entrepreneurship education in colleges and universities can be designed from six aspects: relevance, embedding, translation, adaptation, immersion, naturalization; enhancing the correlation between educational content and demand; increasing the embedding of ecosystem construction; promoting learners Application of knowledge and skill transfer; use school-enterprise cooperation to help learners adapt to economic and social needs; create learning situations to help learners immerse themselves in the continuous learning process; promote the process of innovation and entrepreneurship to naturalize, and guide learners to shift staged learning to lifelong learning.
\end{abstract}

Keywords: innovation 3.0, innovation and entrepreneurship, talent cultivation, optimization research

\section{CCS Concepts}

-Information systems $\rightarrow$ Database management system engines $\quad$ Computing methodologies $\rightarrow$ Massively parallel and high-performance simulations.

\section{INNOVATION PARADIGM EVOLUTION AND INNOVATION 3.0 ANALYSIS}

Innovation 1.0 is the first generation innovation paradigm. Its theoretical basis is the neoclassical economic growth theory. At this stage, innovation is a linear model, that is, the input and output are linearly balanced development, and the government is a top-down administrative management model for innovation activities. In accordance with the requirements of the planned economy, enterprises set up their own research institutions to conduct closed $R \& D$ activities. The driving force for enterprise innovation comes from government demand and self-development, and the value carrier of innovation is only products. Universities are less involved in innovation activities. This stage can be called the "double spiral mode of political production innovation" [1].

Innovation 2.0 is the second generation innovation paradigm, and its theoretical basis is the national innovation system theory. In the period of innovation 2.0, the non-equilibrium between input and output is a non-linear model, emphasizing the open innovation of enterprises, attaching importance to the interaction between government, enterprises and universities, that is, cooperation between industry, universities and research institutes, and jointly building a national innovation system. This period began to focus on market regulation, not only output products, but also output services. In the national innovation system, universities also actively participate in enterprise innovation, but during this period the government is still a top-down management model. This stage can also be called the "three spiral mode of innovation in government and industry" [1].

As the third generation innovation paradigm, Innovation 3.0 is based on the theory of evolutionary economics, emphasizing the national innovation ecosystem, emphasizing the individualized needs, experiences and creativity of users [2]. This is a nonlinear dynamic model, the government transforms its management functions. Instead of managing innovation activities from the top down, it emphasizes multi-governance such as government, market, and society. The government provides an innovation ecosystem. Enterprises, universities, and users are in the innovation ecosystem, and self-organized evolution and innovation, that is, production, education, and research. The "symbiotic" model, innovation not only outputs products, but also services and participant experiences. The university actively participates in and experiences innovation to achieve a symbiotic win-win situation. This stage can be called the "Innovation Four-Spiral Model of Industry, Education , Research and Use".

\section{THE OPTIMIZATION PATH OF INNOVATION AND ENTREPRENEURSHIP EDUCATION IN THE ERA OF INNOVATION 3.0}

Innovative entrepreneurship education is based on the improvement of students' skills and abilities. The independent courses are constructed into an education system that is highly relevant to the whole process of 
innovation and entrepreneurship, emphasizing the education that students use in application and in learning. With the RETAIN model, the innovation and entrepreneurship education of higher vocational colleges can be divided into six parts: Relevance, Embedding, Translation, Adaptation, Immersion, and Naturalization.

Table 1 List of connotation characteristics of the three types of innovation paradigms

\begin{tabular}{|c|c|c|c|}
\hline Innovation paradigm & 1.0 & 2.0 & 3.0 \\
\hline theoretical principle & $\begin{array}{c}\text { Neoclassical economic } \\
\text { theory }\end{array}$ & State innovation system & $\begin{array}{l}\text { Evolutionary Economics } \\
\text { and New Development }\end{array}$ \\
\hline $\begin{array}{l}\text { Innovation subject } \\
\text { (relationship) }\end{array}$ & $\begin{array}{l}\text { Emphasize the internal } \\
\text { of the enterprise unit }\end{array}$ & $\begin{array}{c}\text { Industry-university-researc } \\
\mathrm{h} \text { cooperation }\end{array}$ & $\begin{array}{c}\text { Industry-university-researc } \\
\text { h "symbiosis" }\end{array}$ \\
\hline Innovative features & $\begin{array}{l}\text { Self-dependent } \\
\text { innovation }\end{array}$ & $\begin{array}{c}\text { External collaborative } \\
\text { innovation } \\
\end{array}$ & Innovative ecosystem \\
\hline Innovation mode & linear model & Nonlinear model & Nonlinear dynamic mode. \\
\hline $\begin{array}{c}\text { Innovative value } \\
\text { carrier } \\
\end{array}$ & Product & Product and service & $\begin{array}{c}\text { Product, service and } \\
\text { experience }\end{array}$ \\
\hline $\begin{array}{c}\text { Innovative macro } \\
\text { management } \\
\text { (governance) }\end{array}$ & $\begin{array}{l}\text { Government } \\
\text { management }\end{array}$ & $\begin{array}{l}\text { Government and } \\
\text { management market } \\
\text { regulation }\end{array}$ & $\begin{array}{c}\text { Pluralistic governance of } \\
\text { government, market, } \\
\text { society, etc. }\end{array}$ \\
\hline $\begin{array}{l}\text { Innovation driven } \\
\text { mode }\end{array}$ & $\begin{array}{l}\text { Double helix of demand } \\
\text { and scientific research }\end{array}$ & $\begin{array}{l}\text { Three helix of demand, } \\
\text { scientific research and } \\
\text { competition }\end{array}$ & $\begin{array}{l}\text { Four helix of demand } \\
\text { scientific, research, } \\
\text { competition and symbiosis }\end{array}$ \\
\hline $\begin{array}{c}\text { Enterprise innovation } \\
\text { mode }\end{array}$ & Closed mode & open model & Symbiotic model \\
\hline $\begin{array}{c}\text { Characteristics of } \\
\text { University Innovation }\end{array}$ & $\begin{array}{l}\text { Passive participation in } \\
\text { innovation }\end{array}$ & $\begin{array}{l}\text { Actively participate in } \\
\text { innovation }\end{array}$ & $\begin{array}{l}\text { Take the initiative to } \\
\text { participate in and } \\
\text { experience innovation }\end{array}$ \\
\hline
\end{tabular}

\subsection{Relevance}

Correlation comes from $\mathrm{R}$ in Keller's ARCS motivation theory. In the ARCS motivation theory, it is simply said that learners need to know the impact of learning activities on their status quo and themselves. Correlation in the RETAIN model can be illustrated in terms of target orientation, motivation matching, and familiarity. Target orientation: understand the learner's learning needs and satisfy the learner's learning needs to the greatest extent; motivation matching: the selected teaching strategy matches the students' learning needs; familiarity: the teaching activities can draw on the students' existing knowledge and experience. Or create a situation familiar to learners, and each unit should be related to each other. According to the relevant load theory, the closer the materials involved are to the materials to be learned, the more relevant the theme is to learners, and the higher the level of learning is, the more likely it is to occur [4].

The content of innovation and entrepreneurship education in colleges and universities should not only be consistent with the educational goals, but also should be compatible with the needs of learners, stimulating the internal dynamics of learners, and realizing the cultivation of learners' shallow abilities.

\subsection{Embedding}

Education is not a blunt addition of teaching content to teaching. Instead, students should create curriculum-related problems and scenarios for the learner to experience. Divide the teaching objectives into sub-goals at all levels, and each sub-goal and entrepreneurial The difficulty level is combined to maintain the learner's concern for entrepreneurship by challenging the different levels of the level [5]. The innovative nature of education requires learners to be fully engaged in entrepreneurship in emotional, psychological and intellectual, and to be able to accept changes in the context, truly achieving the integration of teaching content and innovation and entrepreneurship.

In addition to relying on the creative space, classrooms, training bases, etc. of the colleges to carry out offline innovation and entrepreneurship education, we can integrate the innovation 3.0 technology to create a situation that is difficult to present in daily life to carry out education, and to attract learning through the vivid display of educational content in the context. Complete the body learning, such as relying on micro-teaching, AR presentation, VR operation, MR experience, etc. [6].

\subsection{Translation}

The migration stems from the promotion of memory and migration in Gagne's nine teaching events. Mainly refers to: help learners to sort and reorganize the meaning of new construction (new concepts, new knowledge) to promote the preservation and migration of knowledge [7]. The migration in the RETAIN model requires learners to apply the knowledge, skills, etc. learned in a situation to other similar situations and even new situations to promote students' mastery of the knowledge they have learned, thus promoting the formation of students' mobility. .

Effectively use information technology to complete the phased and process evaluation of the "migration" education link in a timely manner, and encourage learners to continuously think, research and innovate on the basis of existing innovation and entrepreneurial achievements, and 
cultivate learners' knowledge transfer ability and environment. Shallow ability such as adaptability [3].

\subsection{Adaptation}

Adaptation is a follow-up concept of migration, derived from the theoretical perspective of cognitive structure development in Piaget [8]. The theory consists of four basic concepts: schema, assimilation, adaptation, and balance. The schema is both cognitive structure, and the construction of cognitive structure is carried out through assimilation and adaptation. Through the interaction of assimilation and adaptation, the dynamic balance is achieved in accordance with environmental requirements, and the dynamic balance between subject and environment is the essence of adaptation. .

Innovate 3.0 technology to achieve remote interconnection between schools and enterprises, to meet the needs of all parties, and to enhance the endogenous motivation of all parties involved. By establishing a school-enterprise cooperation platform, students will be able to understand the needs of professional positions in the direction of innovation and entrepreneurship, and select practical training programs in an individualized way, encouraging learners to apply innovative entrepreneurial knowledge and skills, and carry out real operations in real scenes and problems.

\subsection{Immersion}

Immersion is when people are fully engaged in an activity, their concentration is highly concentrated, and because of the difficulty and skill of the task, the activity can be carried out efficiently and smoothly, reaching a psychological state of forgetting the realm [9].

The "immersion" education link is an important stage of education to train learners to integrate innovation and cross-border skills. By teaching learners how to use the innovative 3.0 technology to create virtual situations, students can create learning contexts based on their own innovative entrepreneurial needs, engage in deep interactions, and learn in innovation and innovation in learning with a good immersive experience. At the same time, the "immersion" link can encourage learners to think about the relationship between innovation and entrepreneurship and professional learning, enhance cross-border innovation awareness, and achieve cross-border cross-learning.

\subsection{Naturalization}

The $\mathrm{N}$ (naturalization) in the RETAIN model comes from the classification of mental motion. Learners are already proficient in the skills they have acquired and are able to use their skills to change their activities to adapt to new environments or to meet new specific situations.

"Naturalization" aims to cultivate learners' habits and abilities to innovate and start a business, and to undertake the important task of helping learners become complex innovative talents. In the openness of innovation and entrepreneurship education in the era of innovation 3.0, encourage learners to actively learn and continue to open innovation [10], cultivate the habit of innovative application of technical skills, naturalize the process of innovation and entrepreneurship, and guide learners to stage learning turn to lifelong learning.

\section{CONCLUSIONS RECOMMENDATIONS}

AND

In the period of Innovation 3.0, the institutions are required to cultivate talents with innovative consciousness, innovative thinking and innovative ability. Using the RETAIN model, the optimization path of innovation and entrepreneurship education in colleges and universities can be designed from six aspects: Relevance 、Embedding 、 Translation 、 Adaptation、Immersion、 Naturalization.

In the multi-innovation ecosystem, setting up a variety of Maker courses is of great significance for cultivating "Innovation 3.0" talents. At the same time, we implement the concept of makers throughout the curriculum and focus on the diversity of teaching content and methods. (1) Pay attention to the era and novelty of curriculum materials, and integrate multi-disciplinary teaching resources. (2) Emphasize the integration of professional knowledge and information technology. (3) Pay attention to the practicality and practicality of the curriculum teaching activities. (4) Focus on the reform of the curriculum evaluation paradigm, combining process evaluation and outcome evaluation.

\section{ACKNOWLEDGMENT}

This study was funded by Research Project of College Student Work of Hubei Province (2018XGJPF4002) ; Experimental Teaching Research Project of HBUE (SY19).

\section{REFERENCES}

[1] W, LI. J,CHANG. MJ,WANG.Innovation 3.0 and innovation ecosystem[J].Studies in Science of Science, 2014, 32 (12) : 1761-1770.

[2] XY,TANG.Study on Maker Talent Training in Higher Vocational Colleges in the Context of "Innovation 3.0". $[\mathrm{J}]$.Forum on Contemporary Education,2019(03):105-111.

[3] YW, LIU.SM,ZHU.Research on Innovation and Entrepreneurship Education in Higher Vocational Colleges in Era of Educational Informatization 2.0[J].Research on Innovation and Entrepreneurship Education in Higher Vocational Colleges in Era of Educational Informatization 2.0,2019,40(08):60-63.)

[4] Glenda A. Gunter,Robert F. Kenny,Erik H. Vick.Taking educational games seriously: using the RETAIN model to design endogenous fantasy into standalone educational games[J].Educational Technology Research and Development . 2008(56):511-537.

[5] Robert F. Kenny , Glenda A. Gunter. Endogenous Fantasy --Based Serious Games:Intrinsic Motivation and Learning [J].International Journal of Social Sciences, 2007,2(1):8-13.

[6] XZ,XU. N,HAO.Towards 2050: Vision and Strategies of Building an Innovation and Entrepreneurship Education 
Ecosystem[J].China Higher Education Research, 2018 (1): 53-56+103.)

[7] KL,HE. WG LI (2002). Teaching system design [M]. Beijing: Beijing Normal University Press.

[8] Piaget, J. (1971). Biology and Knowledge: An Essay on the Relations between Organic Regulations and Cognitive Processes. Chicago, IL: University of Chicago Press.

[9] Csikszentmihalyi, Mihaly.(1990). Flow: The Psychology of Optimal Experience.Lawrence A. Beck Pages 93-94 | Published online: 13 Feb 2018.

[10] ZY,CAO.The Design Strategy of College Teachers Cultivating Innovative Talents--Based on the Rational Consideration of "MOOCs + Flipped Classroom"[J].Forum on Contemporary Education, 2018 (5) :95-102. 